Новікова О. Ф., д.е.н., професор

Азьмук Н. А., д.е.н.

Шастун А. Д., к.е.н.

Інститут економіки промисловості

Національної академії наук Украӥни

м. Київ, Украӥна

DOI: https://doi.org/10.30525/978-9934-26-064-3-19

\title{
РОЗВИТОК КРЕАТИВНИХ ІНДУСТРІЙ В УКРАЇНІ В КОНТЕКСТІ СТАНОВЛЕННЯ ЦИФРОВОЇ ЕКОНОМІКИ
}

Креативні індустрії (creative industries) стають провідним сектором сучасної економіки. Творчі індустрії сприяють створенню бізнес-навичок й розвитку культурних практик, вони потребують нових управлінських підходів при прискореній цифровізації економіки. За останні десять років світовий товарообіг креативної продукції та послуг майже подвоївся та досяг рекордної суми в 624 млрд. доларів США. Поряд 3 економічними вигодами креативна економіка створює також i нематериальні цінності, які відіграють чималу роль у забезпеченні сталого розвитку, орієнтованого на людину [1].

Процеси глобалізації суттєво впливають на національні ринки праці. Цей вплив посилюється за наявності можливостей для робочої сили національних держав здійснювати прикладання своїх трудових зусиль за межами країни. Прискорення цих процесів обумовлено цифровізацією, яка сприяла розвитку глобального та національних цифрових ринків та цифрової зайнятості.

Розвиток культурних та креативних індустрій в Європейському Союзі, де вони визначаються в правових документах і програмах вплинув на формування в Україні креативних індустрій та їх змістовне наповнення. Незважаючи на законодавчу регламентацію змісту креативних індустрій, які містяться в Законі України «Про культуру», вони не мають практичного впровадження ні в концептуальному, ні в управлінському, ні в 
практичному сенсі. Найбільш болючими залишаються питання, які перешкоджають розвитку креативних індустрій. Залишаються невизначеними наслідки впровадження цифрових технологій у цю сферу. Потребують визначення та реалізації питання розподілу повноважень, обов'язків та відповідальності за розвиток креативних індустрій в Україні та їх впливу на економічне зростання, безпечне існування та культурну спадщину.

В новій редакції Закону України [2], креативні індустрії це види економічної діяльності, метою яких є створення доданої вартості і робочих місць через культурне (мистецьке) та/або креативне вираження. Креативні продукти, товари та послуги, що створені/надані за результатами культурного (мистецького) та/або креативного вираження і мають високу додану вартість. Згідно з переліком креативних індустрій [3], який затверджений розпорядженням КМУ від 24.04.2019 р. № 265-р він включає тільки традиційні креативні індустрії: мистецтво, дизайн, архітектуру, кіноіндустрію, літературу та видавничу діяльність, рекламу, комп'ютерне програмування, маркетинг i PR, архіви та музеї, художні промисли тощо.

За результатами експертного опитування, яке проводилось за участі співавторів цієї публікації в Інституті економіки промисловості НАН України з листопада 2019 р. по березень 2020 р. визначилась доцільність включення до креативних індустрій певних видів економічної діяльності.

За поширення та конкретизацію креативних галузей, які будуть сприяти розвитку креативної індустрії, обумовлять іiі становлення та укріплення була більшість експертів (71,3\%). Вони вважають необхідним внесення у перелік видів діяльності, які стосуються досліджень та експериментальних розробок у різних галузях $(71,7 \%)$, вищої освіти $(69,6 \%)$, надання експертних та консультативних послуг (63\%), професійно-технічної освіти (40,2\%), діяльність 3 керування комп'ютерним устаткуванням (37\%), загальної середньої освіти (25\%), діяльності у сфері працевлаштування (23,9\%), початковій освіті (16,3\%), дошкільній освіті $(15,2 \%)$. Зараз у Перелік креативних індустрій включено 
iз Національного класифікатора України тільки один вид економічної діяльності 72.20 «Дослідження й експериментальні розробки у сфері суспільних і гуманітарних наук» 3 розділу 72 «Наукові дослідження і розробки» [4]. Водночас за характером діяльності дослідницька праця $є$ креативною не залежно від сфери эї здійснення.

У Національному класифікаторі України до розділу 72 «Наукові дослідження та розробки» наведено тлумачення згідно 3 яким ця діяльність спрямована на одержання нових знань, розроблення технічних нововведень, виробництво нових матеріалів, продуктів чи пристроїв, впровадження нових процесів, систем та послуг чи значне удосконалення тих, що вже випускалися або були введені в дію. Тому доцільним є включення у Перелік креативних індустрій розділ 72 повністю, 3 такими видами економічної діяльності: 72.11 «Дослідження й експериментальні розробки у сфері біотехнологій», 72.19 «Дослідження й експериментальні розробки у сфері інших природничих i технічних наук».

У сфері вищої освіти відбувається продукування знань, формування та нагромадження людського капіталу. На думку більшості експертів $(69,6 \%)$ доцільно розширити Перелік креативних індустрій сферою вищої освіти. Водночас у Перелік 3 розділу 85 Національного класифікатора включено лише один вид економічної діяльності 85.52 «Освіта у сфері культури». Його доцільно доповнити іншими видами економічної діяльності, що належать до сфери вищої освіти, зокрема: 85.42 «Вища освіта», 85.41 «Фахова передвища освіта», 85.51 «Освіта у сфері спорту та відпочинку». Підтримку з боку експертного середовища щодо включення у Перелік креативних індустрій отримала діяльність у сфері експертних та консультативних послуг. 3 розділу 70 «Діяльність головних управлінь (хед-офісів); консультування 3 питань керування» Національного класифікатора України у Перелік креативних індустрій включено лише ВЕД 70.21 «Діяльність у сфері зав'язків з громадськістю». У Національному класифікаторі системно представлено такий вид діяльності: 
«консультаційні послуги та допомогу компаніям та іншим організаціям 3 питань управління, стратегічного й організаційного планування; фінансового планування та планування бюджету; маркетингових цілей та політики; кадрової політики, встановлення порядку та планування; планування виробництва; забезпечення контролю. А також, спостереження й управління різними підрозділами однієї компанії або підприємства, тобто діяльність головних управлінь» [4]. Тому Перелік креативних індустрій доцільно доповнити такими видами економічної діяльності 70.10 «Діяльність у сфері управлінь головних офісів (хед-офісів)», 70.22 «Консультування 3 питань ведення комерційної діяльності».

Важливим чинником стимулювання розвитку креативних індустрій $є$ процеси цифровізації економіки. На питання «Чи погоджуєтесь Ви 3 твердженням, що процеси цифровізації трудової сфери слугують драйвером розвитку креативних індустрій?» переважна більшість експертів відповіла ствердно $80,6 \%$, не погодилися $14,8 \%$ та 4,6\% не змогли визначитися 3 відповіддю. Отже, переважна більшість експертів вважає за доцільне визначити цифровізацію трудової сфери драйвером розвитку креативних індустрій.

Розвиток креативних індустрій набуває важливого значення саме в період переходу до цифрової економіки, що зумовлено цифровізацією робочих місць та процесу праці. Основні пріоритети для розвитку креативних індустрій в Україні потребують надання додаткових можливостей для поєднання паралельних культурних процесів, створенні ефективної моделі культурного виробництва, забезпечення свободи творчості, стимулювання інноваційного та освітнього потенціалу культури, забезпечення необхідними креативними кадрами, посиленні ролі культури в суспільстві, стимулювання та підтримки міжнародного співробітництва. 


\section{Література:}

1. Креативная экономика - двигатель и катализатор устойчивого развития : по даным центра новостей OOH. URL: http://www.un.org/russian/news/ story.asp?NewsID=20605\#.Wf7VyrVLdWE

2. Закон України «Про культуру» від 14.12.2010 № 2778-VI. URL: https://zakon.rada.gov.ua/laws/show/2778-17

3. Про затвердження видів економічної діяльності, які належать до креативних індустрій. Розпорядження Кабміну № 265-р від 24.04.2019. URL: https://www.kmu.gov.ua/npas/pro-zatverdzchnoyi-diyalnosti-yaki-nalezhat-do-kreativnih-industrij

4. Національний класифікатор України. Класифікація видів економічної діяльності КВЕД ДК 009:2010.

5. Азьмук Н.А. Трансформація зайнятості при переході до цифрової економіки: глобальні виклики та стратегії адаптації: монографія. Київ : Знання, 2019. $335 \mathrm{c}$.

6. Новікова О.Ф., Шамілева Л.Л., Шастун А.Д. Перспективи змін у трудовій сфері при цифровізації економіки за інерційним та цільовим сценарієм. Економічний вісник Донбасу. 2020. № 2. С. 187-199. 